\title{
Audit Fees Determinants: A Study on the Impact of Key Audit Matters Reporting and other Factors
}

\author{
Zuaini Ishak ${ }^{1}$, Shamharir Abidin ${ }^{2}$ \\ ${ }^{1,2}$ Universiti Utara Malaysia, Malaysia \\ zuaini@uum.edu.my ${ }^{1}$, sham1202@uum.edu.my²
}

Article History: Received: 10 November 2020; Revised: 12 January 2021; Accepted: 27January 2021;

Published online: 05April 2021

\begin{abstract}
Knowledge is now an essential source of competitive advantage. Itenhanceseconomic growth and increasescorporate value. In the field of auditing, authority was aware of the need for improved reporting and thus has issued a brand newstandard related to auditor's report. While the new report is expected to enhanceaudit reporting and improve the quality of audit, the move may also increasethe audit costs as auditorsnow needto expandtheir efforts. We analyzed 261 companies listed on Bursa Malaysia and the results indicate that the requirement to improve auditor's communication through enhanced reporting does not influence audit fees. Instead, the study suggests that the company size, poor financial performance and liquidity issue are key determinants of audit fees. The two world's largest audit firms, i.e., PWC and KPMG, are found to charge higher fees than others, possibly for the brand name. This study informs regulators of the influence of the new requirement on audit output costs.It also offers insight into the main drivers for audit pricing following the current reporting requirement.
\end{abstract}

Keywords:audit cost, Key Audit Matters, audit fees, Malaysia

\section{Introduction}

The present paper examines the impact of the mandatory enhanced auditors' reporting on auditing cost. It identifies the determinants of audit fee and audit fees rate during the period surrounding the implementation of the requirement.

The main objective of the audit is to provide 'reasonable assurance' that a company's financial resultsare "true and fair".Auditing adds credibility to the financial statements prepared by management. The auditor's opinion is conveyed in the auditor's report, which is the end product of an audit. However, studies such as by Gray et al. (2011) and Vanstraelen et al. (2012) propose that it is generally accepted that the audit report is not an efficient communication tool to inform the users about the audit and its process. Mock et al. (2013) argue that the report has little informative value. However, the issue is not new. For example, in 1978, a study on auditor's responsibilities described the auditor's report as 'a single symbol that is no longer read'.

The International Auditing and Assurance Standard Board (IAASB), which is the international body for setting auditing standards, has in 2016 approved an auditing standard calling for an improved auditors' report in bid to increase the descriptive nature of the auditor's report.Following the move, the Malaysian Institute of Accountants (MIA) has issued the same set of auditing standards, which wereaffective for audits of financial statements for financial periods ending on or after December 15, 2016. Thus, since 2017 the auditor's report needs to be presented in a revamped format which deemed 'a game-changing and insightful' (Oh, 2017).

The fundamental changes in the enhanced auditor's report include the restructuring of the audit report for readability, specific paragraph to describe 'Going Concern'-i.e. the assumption that an entity will remain in business for the foreseeable future, and any material uncertainty. The new report also requires auditor to provide positive statement about the auditors' independence and fulfilment of other ethical responsibilities. The most significant change, however, is the inclusion of a paragraph on Key Audit Matters (KAM). KAM is a commentary on matters that were of most significance during the audit of public listed companies (PLCs). Arguably, the inclusion of KAM would give investors more clarity or at least an idea of what were the risk areas for company.

While the introduction of the enhanced auditor report is expected to result in improved financial reporting and audit efficiency, auditors may also incur additional audit costs due to increased audit activities and reporting costs. The implementation of KAM, for example, would require auditors to involve in discussion of the matters with audit committee and management in term of form and content. In addition, there is also some possibilities that auditors may increase audit procedures to respond to higher legal liability and reputation loss risk. Given the wider legal exposure and possible incremental audit efforts, it is expected the audit fees will also increase. However, given the audit process is unobservable to clients, auditors might take this opportunity to charge abnormal fees. Excessive increases in audit fees are of concern as it can generate incentives for auditors to comply with client pressure for substandard reporting, thereby eroding audit quality. 
Thus, it is the objective of the present study to examine the impact of the enhanced auditors' reporting on audit fees charged by auditors to their clients after the introduction of the requirement. The present study also seeks to identify the determinants of audit fee during the period surrounding the implementation of the requirement.

Given the introduction of the enhanced auditors' report requirement in December 2016, the investigation on how the new regulation potentially change the audit cost can be considered timely. Excessive auditing fees will provide auditors with incentives to meet client pressure to report inadequately and thus compromise audit efficiency.This study would inform regulators of the influence of the new requirement on audit output costs, and subsequently, would provide insight oncriticaldrivers for audit pricing following the current reporting requirement.

The rest of this paper is organized as follows. Sections II describes the background and presents the research questions. Section III describes the research design and defines variables. Section IV provides statistics and presents the regression results. Section V concludes and suggests future works.

\section{Background and Research Questions}

\section{A. Enhanced auditors' report and Key Audit Matter Reporting (KAM)}

It is reported that public listed companies in Malaysia, spend on average a sum of RM274,000 with a total of RM257 millions paid in 2010, as fee payment to their auditors. Despite the high amount of audit costs paid out, Ali et al. (2006) argue that auditing practice in Malaysia is designed solely to meet legal requirements and also to attract foreign capital investment. Many business do not value the statutory audit work accordingly, and in fact, many still consider auditing as additional cost to business with less benefit.

In Malaysia, most companies are required to appoint qualified auditor to audit their financial statements. The requirement is made mandatory by the Companies Acts 2016 and the now defunct, Companies Acts 1965. Auditors, in discharging their duties, are bound by accepted auditing standards and requirements such as the International Auditing Standards, International Standard on Quality Control (ISQC) 1 and By-Laws (On Professional Ethics, Conduct and Practice) (Abdul Wahab et al., 2011).

In 2015, the IAASB approved a suite of auditing reporting standards effective for audits of financial statements. These standards, which come to effect for financial periods ending on or after 15 December 2016, were set to enhance the information value of the auditors' report by providing greater insights into the audit of the financial statements of an entity. In the same year, the MIA issued the same set of auditing standards that fully adopted the IAASB equivalents, with the same effective date. The implications of these standards are significant and impact all those involved in the financial reporting ecosystem (investors, regulators, management, those charged with governance- such as the Board of Directors and other relevant parties) and not just the auditors.

Bursa Malaysia Securities Berhad has in March 2016 issued amendments to the Main Market and ACE Market listing requirements to complement these enhanced auditor reporting requirements. As the Board of Directors is legally responsible for preparing the financial statements and overseeing the financial reporting process of the company, the Board should proactively engage the auditors on these requirements to discuss the effects of the changes to ensure a seamless transition to the enhanced auditors' report.

The new requirement, as set out in the International Standard of Auditing 701 (Communicating Key Audit Matters in the Independent Auditor's Report)demand an inclusion of a new segment in the auditor's report called Key Audit Matters (KAM). The segment would highlight specific concernsthat to auditor, are most important to the audit. KAM shall be included in a separate section of the auditor's report describing the essence and purpose of KAM. The purpose of communicating KAM is to enhance the communicative value of the auditor's report by providing greater clarification on the audit that has been carried out.

KAM shall provide the users, with information on the areas where the auditor has invested the most time in auditing the financial statements. Areas on which the auditor has expended the most time are also complicated and criticalto the 'true and fair' of the financial statements. It also places in which the directors make use of considerable judgement. Understanding the vital areas during auditing can allow users to understand the financial statements better.

KAM are selected from matters communicated by the auditors to the Board of Directors. Out of these matters, the auditor select those matters which required a significant auditor's attention in the conduct of the audit. Finally, 
the auditor chooses the most relevant issues.The description of each main audit problem will be tailored to the company and will:

(a) Explain why the matter was deemed to be one of the most significant issues in the audit;

(b) Describe how the audit dealt with the matter; and

(c)Provide a reference where the financial statements disclosed this matter.

Other key changes in the enhanced auditors' report include the restructuring of the audit report for readability in particular, the 'Opinion' section is required to be presented first, followed by the Basis for Opinion section, description of the directors' and auditors' responsibilities for Going Concern and enhanced descriptions of the auditors' responsibilities and key features of an audit.

The new requirement will of course, lead to additional audit costs for auditors, owing to increased audit activities and reporting costs. However, given that the proposal for the requirement had been discussed by the professions as early as in 2010, the implementation of the new requirement were very much well anticipated and might not send a shockwave to the audit community. Thus, it is interesting to know the impact of requirement on audit production cost.

Hence, we pose the following research question: "Does the implementation of enhanced auditors' report affects the audit fees paid by clients?"

\section{B. Prior Audit Fees studies}

The literature on determinants factors of audit fee could be dated back to Simunic (1980). In his seminal paper, he models audit fee as a component of the cost of the accounting system. He posits that a profit maximizing auditee pursues to minimize the anticipated cost of the financial reporting system. The cost is made up of three components, i.e the cost of: (i) operating the internal accounting system, (ii) performing external auditing, and (iii) expected losses from deficiencies in the audited financial statements. Prior studies, such as Pratt and Stice (1994), employ this model to study the impact of litigation risk on audit fees.In a similar study, Seetharaman et al. (2002) suggestthat in a more litigious business environment, the auditor will assess higher levels of expected losses due to deficiencies in the audited financial statements, and subsequently increase the audit fees.

Following the introduction of the enhanced auditors' report, where auditors are now subjected to increased scrutiny by authorities and public, the pricing behavior of the audit service might also change. Thus, this period of regulation change provides a valuable setting within which to test the audit fees models, and thereby extending our understanding of pricing issues. Our curiosity then leads to the following research question: "What are the determinants of audit fees during the period surrounding the implementation of the new reporting?"

\section{Research Design and Methods}

This section discusses the sample selection and describes the model employed.

\section{A. Sample Selection}

We obtain the latest initial annual listings of all companies from the official list of companies listed on Bursa Malaysia as at 31 Dec 2016. This source provides extensive entries of all the companies and securities listed on that particular date in the Main Market and ACE Market.The compilation represents the most up-to-date and authoritative reference source available at every year-end. Given that the enhanced auditors' report was first mandated on the audit of companies with the fiscal year end post 15 December 2016, we then selected all companies with financial year end from 15 December 2016 onwards. In order to allow us to make comparison with the prior year's audit (prior to the enhanced auditors'report requirement), all selected companies should also have the prior year Annual Report available or else, dropped from the selection. All the required information were retrieved from the Worldscope Database. Our full sample, which include all the data needed for our main analysis, consists of 291 companies or 582 firm-years over the two-year sample period.

\section{B. Model Estimation}

After the comprehensive process of review and synthesizing the theoretical foundations and the pertinent literature, a research framework was developed to capture the factors that influence auditor fees. We adopt the 
multivariate regression analysis to estimate the influence of regulation change on audit fees. The determinants of audit fees are identified from the variables used by previous studies. For simplicity, the potential variables included in the present study are classified into three categories - change in regulation, client attributes and auditor attributes.

We conducted OLS regressions as a corroborative analysis of the effect of the enhanced auditors' report(we refer as KAM) on audit fees. First, to analyze the effect on fees, we adopted a regression equation close to that used in several previous studies. The model is as follows:

Fees $=\beta_{0}+\beta_{1} \mathrm{kam}+\beta_{2}$ lnAssets $+\beta_{3}$ loss $+\beta_{4}$ roa $+\beta_{5}$ current $+\beta_{6}$ liquidity $+\beta_{7}$ sector $+\beta_{8}$ pwc $+\beta_{9} \mathrm{kpmg}+\beta_{10}$ ey $+\beta_{11} \operatorname{del}+\varepsilon$

In line with previous studies (e.g. Abdul-Wahab et al. 2011) we use the logarithmic transformation of audit fee (lgAUDFEE) to capture the level of audit effort in the audit fee model. Abdul-Wahab et al. (2011) suggest that it is reasonable to conclude that the auditor needs more audit time and more specialized audit personnel to complete the audit investigation. This in turn will result in higher audit fees (O'Sullivan, 2000; Abdul-Wahab 2011). Given that audit quality is unobservable, thus prior studies suggest the use of, amongst others, audit fees to proxy for audit effort.

In addition to the InAudfee measure, we also measure the fees paid relative to company's total assets. This measure (feeperassets) indicates the amount of audit fees paid for every RM1,000 total assets and we refer it as a measure of fee expensiveness. The summary of the dependent and independent variables are as follows:

\section{Dependent Variables (Fees)}

InAudfee

feeperassets

Independent Variables

Enhanced Auditors' Report

kam

$=$ If the new enhanced auditors' report have been included in the annual report, i.e. ' 1 ' if the company's financial year end is 15 December 2016 or later and ' 0 ' if the financial year end is before the date.

\section{Client Attributes}

$\ln$ Assets

loss

roa

current

liquidity

sector

\section{Auditor Attributes}

pwc

$=\quad$ Coded ' 1 ' for PWC auditing firms, ' 0 ' otherwise.

kpmg $=\quad$ Absolute audit fees as measured by the natural logarithm of fees paid to external auditor for the fiscal year end

$=\quad$ Audit fees expensiveness as measured by audit fees paid per RM1,000 total assets $=\quad$ Client size as measured by natural log transformation of total assets

= Dummy variable for companies that recorded a loss (LOSS) in the previous year

$=$ Return on assets, business income (operating income + financial revenue - financial expense)/total assets

$=\quad$ Ratio of current assets to total assets

$=\quad$ Ratio of current assets to current liabilities

$=$ Industry dummy, '1' for companies belonging to the industries that are more difficult and labour-intensive to audit, which are construction; consumer; technology sectors. ' 0 ' otherwise.

= Coded ' 1 ' for KPMG auditing firms, '0' otherwise. 
ey

$=\quad$ Coded ' 1 ' for Ernst \& Young (EY) auditing firms, '0' otherwise.

del $=\quad$ Coded ' 1 ' for Deloitte auditing firms, ' 0 ' otherwise.

\section{Results}

The section presents the descriptive analysis and the results of the multivariate estimations.

\section{A. Descriptive Analysis}

Table 1 presents descriptive statistics for the variables used in the study. Audit fees (lnAudfee) statistics indicates that the 582 companies have spent an average value of 6.239 with a maximum of 5.5974. In untransformed term (not reported in table), the average audit fees paid pre-KAM and post-KAM periods were RM1.163 million and RM1.199 million, respectively. The highest paid audit fees by a single company in the preKAM period was RM25 millions and, in the post-KAM period was RM33 millions. In term of audit fees paid per total assets, the statistics suggest that for every RM1000 assets, a company will spend RM0.45 to pay its auditor.

Table 1. Descriptive Statistics $(n=582)$

\begin{tabular}{lcccc}
\hline Variables & Mean & Std. Dev. & Min & Max \\
\hline lnAudfee & 6.239 & 1.137 & 2.303 & 10.413 \\
feeperassets & 0.454 & 0.510 & 0.003 & 5.598 \\
kam & 0.500 & 0.500 & 0.000 & 1.000 \\
lnAsset & 14.335 & 1.422 & 10.250 & 19.091 \\
loss & 0.132 & 0.339 & 0.000 & 1.000 \\
roa & 5.957 & 10.305 & -116.500 & 75.320 \\
current & 0.495 & 0.357 & 0.009 & 5.268 \\
liquidity & 2.503 & 3.321 & 0.202 & 63.488 \\
sector & 0.247 & 0.432 & 0.000 & 1.000 \\
pwc & 0.103 & 0.304 & 0.000 & 1.000 \\
kpmg & 0.210 & 0.407 & 0.000 & 1.000 \\
\hline del & 0.254 & 0.000 & & \\
\hline
\end{tabular}

Other interesting statistics are that $13 \%$ of the companies reported losses during the period under study and $24.7 \%$ of the companies sampled are operating in construction, consumer and technology sectors. The table also reveals market concentration (65.3\%) of the Malaysian audit market by the four biggest audit firms in the world, known as the "Big 4" firms, i.e. PWC, KPMG, EY and Deloitte. This market share is much lower than in Taiwan (80\% in Chi and Huang 2005) but slightly lower than Australia (64\% in Carey and Simnett 2006). Looking at individual audit firms' market share, EY dominates $25.4 \%$ of the audit market (in term of audit fees) and is followed closely by KPMG with $21 \%$ market share. Another Big 4 firm, i.e. PWC captures around $10 \%$ of the market and Deloitte with merely $10 \%$ of the market's slice. 


\section{B.Multivariate Results}

Table 2 and 3 present the results of the estimations of the audit fees equation. The dependent variables are audit fees (lnAudfee) and audit fee expensiveness (feeperassets) for Model 1 and Model 2, respectively.

Table 2. Multivariate (OLS) Results for Model 1

\begin{tabular}{|c|c|c|c|}
\hline \multirow{3}{*}{ DV } & \multicolumn{3}{|c|}{ Model 1} \\
\hline & \multirow[b]{2}{*}{ Coef. } & \multicolumn{2}{|c|}{ lnAudfee } \\
\hline & & t statistic & $\mathrm{P}$ value \\
\hline Intercept & -1.885 & -5.300 & 0.000 \\
\hline kam & 0.009 & -0.150 & 0.882 \\
\hline lnAsset & 0.560 & 22.360 & 0.000 \\
\hline loss & 0.213 & 1.980 & 0.048 \\
\hline roa & 0.000 & -0.110 & 0.915 \\
\hline current & 0.060 & 0.680 & 0.500 \\
\hline liquidity & -0.032 & -6.650 & 0.000 \\
\hline sector & -0.019 & -0.260 & 0.792 \\
\hline pwc & 0.591 & 4.800 & 0.000 \\
\hline kpmg & 0.214 & 2.430 & 0.015 \\
\hline ey & 0.064 & 0.790 & 0.430 \\
\hline del & 0.117 & 1.390 & 0.164 \\
\hline $\operatorname{Adj}-R^{2}$ & & & 0.625 \\
\hline F-stat & & & 93.040 \\
\hline $\mathrm{P}$ value & & & 0.000 \\
\hline
\end{tabular}

The estimations for both models are significant (p-value $<.00)$ with high explanatory power in predicting audit fees (lnAudfee) and audit expensiveness (feeperassets).The independent variables explain $62.5 \%$ of the absolute audit fees and $25.1 \%$ of audit fee expensiveness. Finally, to assess problems related to multicolinearity, we quantify variance inflation factors (not mentioned here). The low values of these factors (i.e. a maximum value lower than 3.0) do not indicate serious multicollinearity problems.

Five variables are found to significantly determine the level of audit fees paid to auditor while four variables are significantly determined the audit fees expensiveness. Contrary to our expectation, the coefficients of KAM reporting in both models are not significantly different from zero, indicating that audit fees and expensiveness are not increased due to the introduction of KAM reporting in Malaysia. Meanwhile, lnAsset, loss and liquidity are significance at least at $\mathrm{p}<0.05$ and consistent with our prediction. Interestingly, company's size is positive when dependent variable is audit fees (lnAudfee) and negative when the dependent variable is audit fee expensiveness (feeperassets). The results might suggest that bigger companies pay more in term of total audit fees, however, the fee rate, i.e. expensiveness is decreasing for bigger companies. This is to suggest the auditor of bigger companies are enjoying economies of scale in the production of audit work. This is consistent with the finding by Abidin et. al. (2010), who find evidence that large companies in UK, pay lower audit fees rate. 
Table 3. Multivariate (OLS) Results for Model 2

\begin{tabular}{|c|c|c|c|}
\hline \multirow{3}{*}{ DV } & \multicolumn{3}{|c|}{ Model 2} \\
\hline & \multicolumn{3}{|c|}{ feeperassets } \\
\hline & Coef. & t stat & $P$ value \\
\hline Intercept & 3.148 & 10.230 & 0.000 \\
\hline kam & 0.019 & 0.510 & 0.612 \\
\hline $\ln$ Asset & -0.191 & -8.860 & 0.000 \\
\hline loss & 0.150 & 2.060 & 0.040 \\
\hline roa & 0.002 & 0.550 & 0.583 \\
\hline current & -0.003 & -0.060 & 0.953 \\
\hline liquidity & -0.010 & -2.560 & 0.011 \\
\hline sector & -0.049 & -0.950 & 0.344 \\
\hline pwc & 0.295 & 2.750 & 0.006 \\
\hline $\mathrm{kpmg}$ & 0.070 & 1.340 & 0.182 \\
\hline ey & -0.016 & -0.400 & 0.692 \\
\hline del & -0.053 & -1.170 & 0.244 \\
\hline $\operatorname{Adj}-R^{2}$ & & & 0.251 \\
\hline F-stat & & & 12.760 \\
\hline$P$ value & & & 0.000 \\
\hline
\end{tabular}

Loss coefficient reported to be positive and significantly greater than zero. This findings is consistent with the fees paid and its expensiveness are increasing in perceived engagement risk. Meanwhile, the positive coefficient of liquidity suggests companies with higher liquidity are perceived as low in engagement risk and hence, the auditor will charge lower fees and cheaper than companies with low liquidity.

Amongst audit firms, it is evidenced that PWC and KPMG charge higher fee than the other firms. Predicted audit fees is approximately 59 percent higher when the auditor is PWC and 21.4 percent higher when the auditor is KPMG, holding other variables constant. Meanwhile, predicted fee expensiveness is approximately $29.5 \%$ higher when the auditor is PWC. None of other Big Four firms report significant relationship with audit expensiveness.

\section{Further Analysis (kam*individual auditor)}

Prior audit fees studies suggest some auditors command fee premium over other auditors (i.e. charging higher fees than competitors). However, it is not known if some specific auditors charge higher audit fees during the implementation of KAM reporting. In order to investigate this possibility, we interact the KAM variable with individual Big 4 variables.

The results, as presented in Table 4 (lnAudfee) and 5 (feeperassets), suggest that no single audit firm charges audit fees significantly higher than its competitors post KAM implementation. 
Table 4. KAM*Individual Big 4 Analysis for Model 1

\begin{tabular}{|c|c|c|c|}
\hline \multirow{3}{*}{ DV } & \multicolumn{3}{|l|}{ Model 1} \\
\hline & \multirow[b]{2}{*}{ Coef. } & \multicolumn{2}{|l|}{ lnAudfee } \\
\hline & & t statistic & $\mathrm{P}$ value \\
\hline Intercept & -1.887 & -5.240 & 0.000 \\
\hline kam & -0.001 & -0.010 & 0.995 \\
\hline $\ln$ Asset & 0.560 & 22.290 & 0.000 \\
\hline loss & 0.211 & 1.960 & 0.050 \\
\hline roa & 0.000 & -0.120 & 0.903 \\
\hline current & 0.060 & 0.670 & 0.503 \\
\hline liquidity & -0.032 & -6.550 & 0.000 \\
\hline sector & -0.019 & -0.260 & 0.794 \\
\hline pwc & 0.598 & 3.590 & 0.000 \\
\hline kpmg & 0.203 & 1.760 & 0.080 \\
\hline ey & 0.081 & 0.760 & 0.446 \\
\hline del & 0.131 & 1.110 & 0.267 \\
\hline kam*pwc & -0.014 & -0.060 & 0.948 \\
\hline kam*kpmg & 0.022 & 0.130 & 0.897 \\
\hline kam*ey & -0.034 & -0.230 & 0.821 \\
\hline kam*del & -0.028 & -0.170 & 0.866 \\
\hline $\operatorname{Adj}-R^{2}$ & & & 0.625 \\
\hline F statistic & & & 68.180 \\
\hline$P$ value of $F$ & statistic & & 0.000 \\
\hline
\end{tabular}

Overall, for both models, all significant variables reported in the basic models are reported to remain as significant. In addition, the explanatory power in both models (i.e. as shown by the Adjusted-R ${ }^{2}$ ) remain at the same level. However, of the variables that maintain their significance, the P-values reported, suggest slight changes.

Table 5. KAM*Individual Big 4 Analysis for Model 2

Model 2

DV

feeperassets 
Coef. t statistic P value

\begin{tabular}{|c|c|c|c|}
\hline Intercept & 3.150 & 10.140 & 0.000 \\
\hline kam & 0.013 & 0.170 & 0.863 \\
\hline $\ln$ Asset & -0.191 & -8.830 & 0.000 \\
\hline loss & 0.148 & 2.040 & 0.042 \\
\hline roa & 0.002 & 0.540 & 0.589 \\
\hline current & -0.003 & -0.060 & 0.950 \\
\hline liquidity & -0.009 & -2.510 & 0.012 \\
\hline sector & -0.049 & -0.950 & 0.345 \\
\hline pwc & 0.307 & 2.170 & 0.030 \\
\hline kpmg & 0.045 & 0.610 & 0.540 \\
\hline ey & -0.015 & -0.230 & 0.818 \\
\hline del & -0.046 & -0.650 & 0.519 \\
\hline kam*pwc & -0.023 & -0.130 & 0.895 \\
\hline kam*kpmg & 0.049 & 0.460 & 0.644 \\
\hline kam*ey & -0.003 & -0.030 & 0.973 \\
\hline kam*del & -0.014 & -0.140 & 0.886 \\
\hline $\operatorname{Adj}-R^{2}$ & & & 0.251 \\
\hline F statistic & & & 9.550 \\
\hline$P$ value of $F$ statistic & & & 0.000 \\
\hline
\end{tabular}

\section{Conclusion and Future Work}

The present paper examines the impact of the mandatory enhanced auditors' reporting on audit fees. It identifies the determinants of audit fee and audit fees rate during the period surrounding the implementation of the requirement. One particular area of focus is the requirement to communicate KAM in the auditor's report. The inclusion of KAM reporting is aimed to result in better financial reporting; however, it may also increase the audit fees. Also, it is widely accepted that excessive audit fees could affect auditor's independence and ultimately, the quality of the audit. The results of this paper lead us to draw several conclusions. Firstly, the newly introduced enhanced auditors reporting does not seem to drive auditors to increase the audit fees. Thus, the results might suggest that the new requirement does not lead auditor to expand the audit efforts, possibly because the proposal for enhanced reporting has been made known to the profession long before its actual implementations. Secondly, the study also suggests four important determinant variables of the audit fees, i.e. size of the company (lnAsset), poor performance (loss), ability to meet short term obligation (liquidity) and if audited by two particular audit firmsnamely, PWC and KPMG. Our results also suggest that none of the auditors charge higher fee than their competitors during the first year of KAM's introduction. 
This research is subject to a range of limitations. First is the comparatively limited sample size attributable to total dataset unavailability. Secondly, the audit fees model is limited to only the variables included. Thus,in interpreting the findings, these shortcomings have to be taken into account.

\section{Acknowledgment}

This research is funded by a grant (GeranPenjanaan) from Universiti Utara Malaysia (UUM). The authors would like to thank the management of UUM for rendering support to this research.

\section{References}

1. Abdul Wahab, E.A., Mat Zain, M., \& James, K., (2011).Political Connections, Corporate Governance and Audit Fees in Malaysia, Managerial Auditing Journal, 26(5), 393-418. http://doi.org/10.1108/02686901111129562

2. Abidin, S., Beattie, V., \& Goodacre, A. (2010). Audit Market Structure, Fees and Choice in aPeriod of Structural Change: Evidence from the UK, British Accounting Review, 42(3), 187-206. http://doi.org/10.1016/j.bar.2010.04.002

3. Ali, A., Haniffa, R., \& Hudaib, M. (2006). Episodes in the Malaysian Auditing Saga. Managerial Auditing Journal, 21(7), 684-701. http://doi.org/10.1108/02686900610680495

4. Oh, E. (2017, March 4). Has anyone noticed the new audit reports? The Star Online, Retrieved from https://www.thestar.com.my

5. Gray, G. L., Turner, J. L., Coram, P. J. \& Mock, T. J. (2011). Perceptions and Misperceptions Regarding the Unqualified Auditor's Report by Financial Statement Preparers, Users, And Auditors. Accounting Horizons, 25(4), 659-84. https://doi.org/10.2308/acch-50060

6. Mock, T. J., Bédard, J., Coram, P.J., Davis, S.M., Espahbodi, R. \& Warne, R.C. (2013). The Audit Reporting Model: Current Research Synthesis and Implications. AUDITING: A Journal of Practice \& Theory, 32(Supplement 1), 323-351. https://doi.org/10.2308/ajpt-50294

7. O'Sullivan, N. (2000). The Impact of Board Composition and Ownership on Audit Quality: Evidence From Large UK Companies. The British Accounting Review. 32(4), 397- 414. https://doi.org/10.1006/bare.2000.0139

8. Pratt, J., \& Stice. J. D. (1994). The Effects of Client Characteristics on Auditor Litigation Risk Judgments, Required Audit Evidence, and Recommended Audit Fees. The Accounting Review. 69(4), 639-656.

9. Seetharaman, A., Gul. F., \& Lynn. S. (2002). Litigation Risk and Audit Fees: Evidence from UKFirms Cross-Listed on US Markets. Journal of Accounting and Economics. 33 (February), 91115.

10. Simunic, D.A. (1980) The Pricing of Audit Services: Theory and Evidence. Journal of Accounting Research, 23, 183-226. http://doi.org/10.2307/2490397

11. Vanstraelen, A., Schelleman, C., Meuwissen, R. \& Hofmann, I. (2012). The Audit Reporting Debate: Seemingly Intractable Problems and Feasible Solutions. European Accounting Review, 21(2), 193-215. https://doi.org/10.1080/09638180.2012.687506 